\title{
Isolation and Characterization of Halotolerant Bacteria from Ezzu River Amansea, Awka, Anambra State
}

\author{
Agu K. C. ${ }^{1, *}$, Nmecha C. O. ${ }^{1}$, Nwaiwu M. O. ${ }^{1}$, Ikedinma J. C. ${ }^{1}$, Awah N. S. ${ }^{1}$, Eneite, H. C. ${ }^{1}$, \\ Victor-Aduloju A. T. ${ }^{2}$, Umeoduagu N. $^{3}$, Onwuatuegwu, J. T. C. ${ }^{3}$ \\ ${ }^{1}$ Department of Applied Microbiology and Brewing, Nnamdi Azikiwe University, PMB 5025, Awka, Nigeria \\ ${ }^{2}$ Department of Food Science and Technology, Nnamdi Azikiwe University, PMB 5025, Awka, Nigeria \\ ${ }^{3}$ Department of Microbiology, Tansian University, Umunya, Nigeria
}

Copyright $\subset 2017$ by authors, all rights reserved. Authors agree that this article remains permanently open access under the terms of the Creative Commons Attribution License 4.0 International License

\begin{abstract}
Halotolerant bacteria are microorganisms that can grow over a large variety of salt concentrations but thrive better in low salinities. This group of bacteria is known to be diverse in nature and can be isolated from the soil, water, and even some rocks. Their compatible solutes serve as survival mechanism when the organisms are exposed to high salinities. Halotolerant bacteria have been applied in the production of antimicrobial substances, in food biotechnology, in biological waste treatment, and in the use of Biosurfactants for bioremediation purposes. Halotolerant bacteria are made up of both Gram-positive bacteria and Gram-negative bacteria in different genera like Staphylococcus, Micrococcus, Bacillus, and Pseudomonas. This research emphasized on the isolation of halotolerant bacteria from Ezzu River, Amansea, Awka, Anambra state using nutrient medium supplemented with different salt (sodium chloride) concentrations and Marine Agar. Pour plate method was used for the isolation of the bacterial strains. The isolates which were yellow and creamy white in color were labeled A, B, and C and their morphological characteristics, noted. They were further Gram stained. The three isolates were Gram-positive cocci and appeared in clusters. They were non-motile. Further characterization was done using biochemical test: catalase test, coagulase test, citrate, and urease and carbohydrate fermentation of different sugars. After the analyses carried out on the three isolates, the halotolerant bacteria suspected to be present in Ezzu River, Anambra state were Staphylococcus aureus, Staphylococcus lentus, and Micrococcus luteus.
\end{abstract}

Keywords Halophiles, Halotolerant Bacteria, Salt Concentration, River, Isolate

\section{Introduction}

Life on Earth is greatly characterized byitsrichvariety
(Wilson, 1992) ${ }^{[1]}$. This is especially true for different species of nematodes, arthropods, bacteria, and fungi (Hammond, 1995), and for organisms from ecologically extreme environments (extremophiles) ${ }^{[2]}$. Extreme environments were long considered to be free of life. However with intense research recently a wide diversity of extremeophilic microorganisms have been discovered (Turk et al. , 2011) ${ }^{[3]}$. Extremophilicmicroorganismscansurviveinextremeenviron mentssuchasunusuallevelsofsalt, $\mathrm{pH}$, pressure, and temperature and those which are adapted to thrive in hypersaline habitats are considered halophiles (Kumar and Gummadi, 2009) ${ }^{[4]}$.

Halophiles can be grouped into three upon their response to $\mathrm{NaCl}$ : slightly halophiles, moderately halophiles, and extremely halophiles with optimal growth rates at $2-5 \%$, $5-20 \%$, and $20-30 \% \mathrm{NaCl}$, respectively (Ollivier et al., 1994; Kekar, 2004; Hedi et al., 2009) ${ }^{[5]}$. It is important to differentiate halotolerant organisms from halophiles. According to Kushner (1968), halotolerant organisms are organisms that can grow in both low and high salinities while halophiles are organisms that require high salinities for growth ${ }^{[6]}$.

The isolation of extreme ophiles can occur from environments in which they are not expected to be actively growing (Echigo et al., 2005) ${ }^{[7]}$. This makes it possible to isolate halotolerant or even halophilic bacteria from a wide range of environments including fresh water (Schieper et al., 1997; Purdy et al., 2004; Oren, 2008) ${ }^{[8]}$. A good example of halotolerant bacteria is the Staphylococcus genus which can grow well in both fresh water and at $\mathrm{NaCl}$ concentrations as high as 1.7-2.6 $\mathrm{M}$ or even higher (Oren, 2006) ${ }^{[9]}$. Two principal mechanisms have been evolved by halophilic and halotolerant microorganisms for adaptation in saline environments: (i) salt-in-cytoplasm and (ii) compatible solute strategies (Mevarech et al., 2000; Tehei et al., 2002; Roberts, 2005) ${ }^{[10]}$. It was reported that moderately halophilic bacteria, Marinobacter idiomarina, Halomonas strains and other halotolerant organisms are able to degrade organic 
pollutants, organic nitrogen compounds (found in foods), organic materials, fertilizers, poisons, and explosives (Garcia et al., 2004; Abdelkafi et al., 2006; LeBorgne et al., $2008)^{[11]}$. Moreover, since they are metabolically different and able to adapt to extreme salinity, they could be considered suitable candidates for bioremediation of hypersaline environments (Vreeland, 1992; Ventosa et al., 1998; Le Borgne et al., 2008) ${ }^{[12]}$.

Although there are no official definitions for the generic term river as applied to geographic features in some countries or communities a river is defined by its size. Sometimes a river is defined as being larger than a creek (Hawkes, 1975) but not always ${ }^{[13]}$. A river is a natural flowing watercourse, usually fresh water, flowing towards an ocean, sea, lake, or another river (Hawkes, 1975) ${ }^{[13]}$. The Ezzu River in Amansea, Awka, Anambra state (otherwise known as Amansea River) is a tributary of River Niger and derives its source from Agbuogugu community in Enugu state and flows through Orjito Amansea. The river is also a source of drinking water to the people of Amansea and neighboring communities (NaijaGists.com, 2013) ${ }^{[14]}$.

The aim of this research is to explore any novel halotolerant bacteriaat Ezzu River, and to examine their morphology and cultural characteristics.

\section{Materials and Methods}

\section{Sample Collection}

Water samples were collected from four different parts of Ezzu River using $10 \mathrm{ml}$ sterile syringe. Composite samples were obtained at different sampling points and depths of $30 \mathrm{~cm}$ below the water surface. This was done by dipping the syringe into the river up to $30 \mathrm{~cm}$ below and pulling the plunger to aspirate $10 \mathrm{ml}$ of sample. The samples were transported to the laboratory in ice chest and stored at $4{ }^{\circ} \mathrm{C}$ until used for isolation of the strains.

\section{Media Preparation}

Three different media were prepared according to the manufacturer's instructions with slight modifications for the isolation of bacterial strains:

- Nutrient medium supplemented with 5\% sodium chloride $(\mathrm{NaCl})$.

- Nutrient medium supplemented with $10 \%$ sodium chloride $(\mathrm{NaCl})$.

- Marineagar (composed).

- Mannitol Salt agar
- $\quad$ Nitrofuran media (FTO, agar).

The media were autoclaved at $121^{\circ} \mathrm{C}$ for 15 minutes.

\section{Isolation of Bacteria}

Ten-fold serial dilution of the water sample was carried out using sterile distilled water as diluents (American public health association, 1925 $)^{[15]}$. Aliquots $(0.1 \mathrm{ml})$ of $10^{-1}, 10^{-2}$ and $10^{-3}$ were plated out using pour plate method. The aliquots were cultured in duplicates for each medium. They were incubated at $37^{\circ} \mathrm{C}$ for 72 hours. After the incubation period, there were deep yellow, bright yellow and creamy white colonies. Different colonies were picked and sub-cultured on nutrient agar (supplemented with 5\% sodium chloride) to obtain pure cultures (American public Health Association, 1925) ${ }^{[15]}$.

\section{Plate Count}

The developing colonies were counted after pour plate method and the mean total bacterial count recorded using the formula: Total viable count=(N/VD) $\times 10$

Where, $\mathrm{N}=$ mean colony count $\mathrm{V}=$ volume of aliquot plated out $\mathrm{D}=$ dilution factor used.

\section{Characterization and Identification of Isolates}

The isolates were grown on selective media, such as Mannitol salt agar for Staphylococcus aureus and Staphylococcus lentus, nitrofuran media for Micrococcus lentus and were chosen for further characterization. Isolates were examined for colony morphology with emphasis on pigmentation, form, elevation, and margin. Gram-staining, motility test, and other biochemical tests such as catalase, coagulase citrate, urease, and sugar fermentation tests viz. glucose, galactose, fructose, maltose, sucrose and lactose were carried out.

\section{Results}

Colonies isolated in the nutrient medium containing 5\% and $10 \% \mathrm{NaCl}$ (from dilutions $10^{-1}$ and $10^{-2}$ ) were a total of 3 halotolerant strains. These strains were examined and characterized morphologically as well as biochemically. The mean bacteria count is shown in table 1 . The results obtained from the morphological and biochemical characterization of the isolates are shown in table 2 . 
Table 1. Mean Total Bacterial Count.

\begin{tabular}{|c|ccc|}
\hline \multirow{2}{*}{ Medium } & \multicolumn{3}{|c|}{ Mean total bacterial count of appropriated illusions $\pm \mathrm{SD}(\mathrm{cfu} / \mathrm{ml})$} \\
& \multicolumn{2}{|c|}{$10^{-1}$} & $10^{-2}$ \\
\hline $\mathrm{NA}+5 \% \mathrm{NaCl}$ & $1.42 \times 10^{5} \pm 1.50$ & $9.90 \times 10^{4} \pm 1.00$ & $9.00 \times 10^{4} \pm 2.00$ \\
\hline $\mathrm{NA}+10 \% \mathrm{NaCl}$ & $9.80 \times 10^{4} \pm 2.00$ & $8.50 \times 10^{4} \pm 1.00$ & $7.15 \times 10^{4} \pm 1.50$ \\
\hline
\end{tabular}

Keys: NA= Nutrient agar

$\mathrm{SD}=$ Standard deviation

$\mathrm{cfu} / \mathrm{ml}=$ Colony forming unit per milliliter

Table 2. Morphological and Biochemical Characteristics of the Isolates.

\begin{tabular}{|c|c|c|c|}
\hline Isolates & A & $\mathrm{B}$ & $\mathrm{C}$ \\
\hline Pigmentation & Bright yellow & Creamy white & Deep yellow \\
\hline Form & Circular & Irregular & Circular \\
\hline Elevation & Raised & Flat & Raised \\
\hline Margin & Entire & Entire & Entire \\
\hline Gram's reaction & +ve, cocci, irregular clusters & +ve, cocci, irregular grape-like clusters & +ve, cocci, grape-like clusters \\
\hline Motility & Non-motile & Non-motile & Non-motile \\
\hline Catalase & $+\mathrm{ve}$ & $+\mathrm{ve}$ & $+\mathrm{ve}$ \\
\hline Coagulase & $-\mathrm{ve}$ & -ve & $+\mathrm{ve}$ \\
\hline Citrate & -ve & +ve & $+\mathrm{ve}$ \\
\hline Urease & $+\mathrm{ve}$ & -ve & $+\mathrm{ve}$ \\
\hline Glucose & A only & $A \& G$ & $A \& G$ \\
\hline Galactose & wA \& G & wA \& G & wA only \\
\hline Fructose & Aonly & wA only & A only \\
\hline Maltose & Nor eaction & No reaction & wA only \\
\hline Sucrose & wA only & A only & wA only \\
\hline $\begin{array}{c}\text { Lactose } \\
\text { Suspected organism }\end{array}$ & $\begin{array}{c}\text { No reaction } \\
\text { Micrococcus luteus }\end{array}$ & $\begin{array}{c}\text { No reaction } \\
\text { Staphylococcus lentus }\end{array}$ & $\begin{array}{c}\text { wA only } \\
\text { Staphylococcus aureus }\end{array}$ \\
\hline
\end{tabular}

Keys: + ve $=$ positive result

-ve $=$ negative result

$\mathrm{A}=$ acid production

$\mathrm{G}=$ gas production

$\mathrm{wA}=$ weak acid production

\section{Discussion}

Extremophiles have been isolated from environments in which they are not expected to be actively growing (Echigo et al., 2005) $)^{[7]}$. Therefore, halotolerant bacteria can also be isolated from a wide range of environment, including fresh water (Schieper et al., 1997; Purdy et al., 2004; Oren, $2008)^{[8]}$.

This research has shown that bacteria isolated from the sample collected from Ezzu River, Anambra state were group of halotolerant bacteria with different phenotypic characteristics (Table2). During the past decades, the studies on the ecology, physiology and taxonomy halophilic and halotolerant organisms revealed an impressive diversity (Oren, 2002) ${ }^{[16]}$. In this study, all the isolates grew on nutrient medium supplemented with $5 \%$ and $10 \% \mathrm{NaCl}$ respectively, no growth was observed on marine agar. This indicates that the isolates are halotolerant organisms which are in agreement with those reported by Bowers et al., (2009) who reported that halotolerant bacteria can grow over a variety of salt concentrations but grow optimally in low salt concentrations ${ }^{[17]}$. Verma, (1993) also reported growth of Staphylococcus in nutrient medium containing $10 \% \mathrm{NaCl}$ which is also a normal salt concentration for halotolerant organisms ${ }^{[17]}$. However, in a study carried out by Parker (1986), he discovered that the halotolerant bacterium Micrococcus luteus could tolerate up to $25 \%$ $\mathrm{NaCl}^{[18]}$.

Halotolerant bacteria grow best at the temperature range of $28^{\circ} \mathrm{C}-37^{\circ} \mathrm{C}$ on media supplemented with $3-5 \% \mathrm{NaCl}$. This study agreed with that of Jasem, (2014) who isolated halotolerant bacteria from Weston Park pond and Dew pond in Derbyshire Peak District in Sheffield and observed the growth of these organisms at temperature range of $35^{\circ} \mathrm{C}-$ $37^{\circ} \mathrm{C}$ on media supplemented with $2-3.5 \% \mathrm{NaCl}^{[19]}$.

The phenotypical characteristics suggested that isolate A is Micrococcus luteus. This is due to its bright yellow pigmentation, circular form, raised and its entire margin. Isolate A also stained Gram positive, cocci in irregular clusters and tested negative for motility and coagulase test. 
This is in agreement with the reports of Ventosa et al., (1988) on the Biology of moderately halophilic bacteria ${ }^{[20]}$. Isolates Band $\mathrm{C}$ showed characteristics typical of the genus Staphylococcus but were differentiated on their ability to convert fibrinogen to fibrin (coagulase test). Isolate $\mathrm{C}$ tested positive for coagulase test suggesting it is Staphylococcus aureus and based on other biochemical tests, isolate B may be Staphylococcus lentus. Oren, (2006) stated that a good example of halotolerant bacteria is the Staphylococcus genus which can grow well in both fresh water and at $\mathrm{NaCl}$ concentrations as high as $1.7 \mathrm{M}-2.6 \mathrm{M}$ or even higher ${ }^{[9]}$.

The results from this research revealed that Micrococcus luteus, Staphylococcus aureus, and Staphylococcus lentus are halotolerant organisms. These organisms could be exploited for bioremediation and transformation of range of organic pollutants in pongs, streams, and rivers (Okoh, $2003)^{[20]}$.

\section{Conclusions}

Three organisms were successfully isolated from $E z z u$ River, Anambra state that could grow in salinity up to $5 \%$ and $10 \%$ sodium chloride $(\mathrm{NaCl})$. This salinity is not particularly too high and is approximately equivalent to the salinity of the river, after checking that of the river and comparing them. This also indicates that halotolerant organisms thrive better at low salinities. It was much harder for these organisms to adapt to increased salinity and that was why they could not grow on marine agar. But in rich medium (nutrient medium with $5 \%$ and $10 \% \mathrm{NaCl}$ ), the precursors of compatible solutes are present allowing easy accumulation of the compatible solutes. This serves as a method of adaptation for the organisms in saline environments (American Public Health Association, $1925)^{[15]}$.

The compatible solutes of halotolerant bacteria are useful as stabilizers of biomolecules, and whole cells. Biopolymers, such as Biosurfactants are of interest for microbially enhanced oil recovery. Their ability to thrive in salty environments suggests their possible use for bioremediation purposes $\left(\right.$ Okoh, 2003) ${ }^{[20]}$.

\section{REFERENCES}

[1] Wilson, E. O. (1992). The diversity of life. Cambridge: MA, Harvard University Press.

[2] Hammond, P. M. (1995). Practical approaches to the estimation of the extent of biodiversity in speciose groups. In Biodiversity Measurement and Estimation. Hawksworth, D. L. (ed). London, Chapman and Hall. , pp. 119-136.

[3] Turk, M., Plemenitaš, A. and Gunde-Cimerman, N. (2011). Extremophilic yeasts: Plasma membrane fluidity as determinant of stress tolerance. Fungal Biology, 115:950-958.
[4] Kumar, S. and Gummadi, S. N. (2009). Osmotic adaptation in halotolerant yeast, Debaryomyces nepalens is NCYC 3413: Role of osmolytes and cation transport. Extremophiles, 13:793-805

[5] Ollivier, B., Caumette, P., Garcia, J. L. andMah, R. A. (1994). Anaerobic bacteria from hypersaline environments. Microbiology Molecular Revolution, 58:27-38.

[6] Kushner, D. J. (1968). Halophilic bacteria. Advance Applied Microbiolog., 10:73-99.

[7] Echigo, A., Hino, M., Fukushima, T., Mizuki, T., Kamekura, M. and Usami1, R. (2005). Endospores of halophilic bacteria of the family Bacillaceae isolated from non-saline Japanese soil may be transported by Kosa event (Asian dust storm). Saline Systems, 8:1-13.

[8] Schieper, C., Holben, W. and Klenk, H. (1997). Recovery of Crenarchaeotal ribosomal DNA sequences from freshwater-lake sediments. Applied Environmental Microbiology, 63:321-323.

[9] Oren, A. (2006). Life at high salt concentrations. Ecophysiological and biochemical aspects. In The Prokaryotes, A Hand book on the Biology of Bacteria ( $3^{\text {rd }}$ edn), 2:263-282.

[10] Mevarech, M., Frolow, F. and Gloss, L. M. (2000). Halophilicenzymes: Proteins with a Grain of Salt. Biophysio Chemical, 86:155-164.

[11] Garcia, M. T., Mellado, E., Ostos, J. C. and Ventosa, A. (2004). Halomonasorganivorans sp., a moderate halophile able to degrade aromatic compounds. International Journal of Systematic Microbiology, 54:1723-1728.

[12] Vreeland, R. H. (1992). The family Halomonadaceae. The Prokaryotes. A hand book on the biology of bacteria: Ecophysiology, isolation, identification, applications ( $\left.2^{\text {nd }} \mathrm{edn}\right)$. Balows, A., Trüper, H.G., Dworkin, M., Harder, W. and Schleifer, K. H. (eds): New York, Springer Verlag, 6:31813188 .

[13] Hawkes, H. A. (1975) River zonation and classification. River Ecology (Blackwell), 312-374.

[14] Naija Gists.com (January19, 2013). 15corpses found on Ezzu River in Awka, Anambra-Enugu states boundary. Available from naijagists.

com/15-corpses-found-on-ezzu-in-awka-anambra-enugu-state s-boundary. Accessed on June 10, 2016.

[15] Standard Methods for the examination of Water and Sewage. American Public Health Association, 370 Seventh avenue, New York. (1925)

[16] Oren, A. (2002). Halophilic Microorganisms and Their Environments, Kluwer Academic Publishers.

[17] Bowers, J. K., Mesbah, M. N. and Wiegel, J. (2009). Biodiversity of polyextremophilic bacteria: Does combining the extremes of high salt, alkaline $\mathrm{pH}$ and elevated temperature approach a physico-chemical boundary for life. Saline Systems, 5:9-16.

[18] Agu, K. C., Bassey, E.E., Iloanusi, C.A., Awah, N. S., Okeke, B.C., Anaukwu, C. G., Ezenwa, C.U., Orji, M.U. and Okafor, A. C. (2014a). Isolation and Characterization of Microorganisms from Oil Polluted Soilin Kwata, Awka South, Nigeria. American Journal of Current Microbiology, 3:46-59. 
[19] Okoh, AL (2003). Biodegradation of Bonny Light Crude Oil in Soil Microcosm by some Bacterial Strains isolated from Crude Oil flow Stations saver pits in Nigeria. African Journal Biotechnology 2(5):104.

[20] Agu K. C., Okafor, F. C., Amadi, O. C., MbachuA. E., AwahN. S. and Odili, L. C. (2014c). Production of mannanase enzyme using Aspergillus spp. isolated from decaying palm press cake. Scholars Academic Journal of Biosciences, 2(12A):863-870

[21] Anaukwu, C. G., Ezemba, C. C., Anakwenze, V. N., Agu, K. C., Okeke, B. C., Awah, N. S. and Ekwealor, I. A. (2016). Effect of biosurfactant produced by Citrobacter murliniae AF025369 and a synthetic surfactant on degradation of crude oil. Edorium Journal of Microbiology, 2:1-6.

[22] Ifediegwu, M. C., Agu, K. C., Awah, N.S., Mbachu, A.E., Okeke, C.B., Anaukwu, C.G., Uba, P.O., Ngenegbo, U.C., Nwankwo, C. M. (2015). Isolation, growth and identification of chlorpyrifos degrading bacteria from agricultural soil in Anambra State, Nigeria. Universal Journal of Microbiology Research 3(4):46-52.

[23] Mbachu, A. E., Onochie, C. C., Agu, K. C., Okafor O. I. and Awah N. S. (2014). Hydrocarbon degrading potentials of indigenous bacteria isolated from auto-mechanic workshops at Mgbuka-Nkpor, Nigeria. Journal of Global Bioscience, 3(1):321-326. 